\title{
EFFECT OF SUPPLEMENTING DIFFERENT LEVELS OF OPTEIGEN AS A REPLACER TO SOYBEAN ON THE STEERS'PERFORMANCE
}

\author{
Eweedah, N. M.; M. I. Bassuony, A. M. Abd EL-Razik and M. \\ A. Abd El-Baky \\ Department of Animal Production, Faculty of Agriculture Kaferlsheikh \\ University
}

\begin{abstract}
This study was conducted to evaluate the effect of using Opitgen feed additives as a replacer to soybean meal in the diet of fattening Holistien calves. Fifteen Holistien calves with an average initial weight $260.26 \pm 13.25 \mathrm{~kg}$ and aged seven month were divided into three groups (five in each) based on initial body weight and age. Calves were housed under open sheds. Calves in the first group were fed the control ration (without additives) while the steers in the second and third groups were fed the control ration with addition 75 or 100 gm. of Optigen II (Alltech, Lexington, KY)as a replacer to $0.421 \mathrm{~kg}$ of soybean meal which is represented of $1.35 \%$ on dry matter basis (Opt. 75)or100 gm Optigen II(Alltech, Lexington, KY)as a replacer to $0.558 \mathrm{~kg}$ of soybean meal which is represented of $1.84 \%$ on dry matter basis (Opt. 100) for 105 days. Dry matter intake, nutrients apparent digestibility, rumen activity, growth performance and economic efficiency were determined.

The results showed that dry matter intake, organic matter, crude protein, ether extract and crude fiber as well as total digestible nutrients and digestible crude protein were not affected by the different experimental diets. The animals in G2 (Opt.75) had the highest digestibility coefficients of all nutrients followed by animals in G3 (opt. 100), while the control group had the lowest values. The nutritive values expressed as TDN or DCP for animals in G2 (Opt. 75) and G3 (Opt. 100) were slightly higher ( $P>0.05)$ compared with the control group. There were no significant differences $(p>0.05)$ in $\mathrm{pH}$ value among the different experimental group during the trial, the pHvalues are within the normal range. But there were significantly $(p<0.05)$ differences among the different groups concerning ruminal ammonia- $\mathrm{N}$ concentration $\left(\mathrm{NH}_{3}-\mathrm{N}\right.$ whereas the G3 (100 g Opt.) recorded the highest $\mathrm{NH}_{3}-\mathrm{N}$ concentration which were $7.13,8.03$ and $9.56 \mathrm{mg} / 100 \mathrm{ml}$ rumen liquor for $\mathrm{G} 1$, G2 and G3, respectively. The concentration of TVF's in the rumen liquor of animals in group II supplemented with optigen (75 g Opt.) was higher significantly $(p<0.05)$ compared with the other groups. The average daily gain for G1, G2 and G3 were 1.35, 1.39 and $1.25 \mathrm{~kg} /$ day, respectively. Calves in G2 recorded the highest value of average daily gain compared to the other groups. Also, the animal in G2 (75 g Opt.) recorded the better value of feed conversion compared to the other groups, it improved by 5.21 and $14.04 \%$ compared with the control and G3, respectively). The best economic efficiency was recorded by the G2 while the lowest economic efficiency was recorded by the G3 while, the control group had the intermediate value.
\end{abstract}


Finally it can be recommended that the supplementation of optigen at level 75 $\mathrm{gm} /$ day (1.35\% on DM basis) in the diets of Holistien calves.

Keywords: soybean meal, optigen, digestibility, rumen fermentation, slow release urea

\section{INTRODUCTION}

In Egypt, shortage of feed supply may be considered the major constraint to further increase in animal production. The high cost of feed grains and many high-protein grains may make the use of urea as a protein source very cost-effective in animal feeding. Urea contains about $45 \%$ nitrogen (protein contains 16\% nitrogen). Therefore, when urea is converted to protein, the crude protein equivalent value of urea is about $281 \%$. It must be recalled that urea contains no other useful feed components such as energy, minerals, or vitamins. When too much ammonia escapes the rumen because the microbes are not able to utilize enough of it for protein, the capacity of the liver for excretion urea is decreased then over toxicity can be occurring.It is vitally important that the right level of urea is fed and that there will be sufficient bacterial action to produce protein.

A potential way to minimize excess ammonia accumulating in rumen reaching the liver is to increase microbial utilization of ammonia by modulating its appearance in therumen. To achieve this goal, some researchers have used microbial urease inhibitors, withmixed results (Whitelaw et al., 1991; Ludden et al., 2000). As recent research suggests, inability of the rumen microorganisms to synthesize sufficient quantities of all amino acids needed to prevent deficiencies or imbalances may be a major factor responsible for the lowered animal performance obtained with urea diets (William Chalupa, 1968). Soybean meal (SBM) has long been used as a prominent source of crudeprotein for ruminants, however, with its increasingprice, the use results in ultimately higher costof production(Chalupa, 2007). Therefore, the use of urea as a non-protein nitrogen (NPN) replacement is attractive inruminant diets because of its low cost compared with other protein feeds such as SBM with high rumendegradability(Wanapat et al., 2009 and Xin et al., 2010).

Numerous attempts have been made over the years to control the ruminal release of urea by combining urea with starch (Deyoe et al., 1968), molasses (Males et al., 1979), cellulose (Conrad and Hibbs, 1968), or oils (Owens et al., 1980). The development of products that slow the ruminal release of ammonia without limiting the extent of urea degradation in the rumen has been challenging (Males et al., 1979). 
In 2005 Alltech INC. (Lexington, KY) developed and commercialized a controlled- release urea product (Optigen) that involves coating urea. Optigen II(Alltech, Lexington, $\mathrm{KY}$ ) is a blended urea product with an intermediate $\mathrm{N}$ release rate that is less than urea and greater than some of the slow release urea (SRU) products described above. Optigen II provides high N concentration at $256 \% \mathrm{CP}$ compared with true protein sources such as soybean meal at $53 \% \mathrm{CP}$ on DM basis (Tikofsky and Harrison 2007).

The chemical analysis of optigen with (Alltech Laboratory Lexington, US) was $0.2 \%$ humidity, $256 \%$ crude protein, total nitrogen $41 \%$ and ether extract $12 \%$.Optigenwasblended non-protein nitrogen (NPN) source for ruminants andrumen degradable nutrient-dense nitrogenenhances the growth of fiber-utilizing bacteria andopens up space in the diet for digestible fiber and energy andimproves the efficiency of microbial protein synthesis. The factors to use optigen were $41 \% \mathrm{~N}, 256 \% \mathrm{CP}$ and $50 \%$ release in the first 12 hours and $95 \%$ release in 24-36 hours. The aims of the present study was to investigate the effect of Optigenll(Alltech, Lexington, KY) as a slow release of source of amonia to replacement of soya bean meal in the rations of Holstein calves on the digestibility, rumen fermentation, animals performance and economic efficiency.

\section{MATERIAL AND METHODS}

The present work was carried out a commercial animal production farm (el hamamy station) in Abo-Homous, EL-Behira Governorate, Egypt, in co-operation with Department of Animal Production, Faculty of Agriculture, Kafrelsheikh University.

The experiment was conducted from November 2014 through February of 2015.the trial period was 105 days. Fifteen Holistien calves with average initial weight $260 \pm 13.25 \mathrm{~kg}$ and average age seven month weredivided into three groups(five in each) based on initial body weight and age. Calves were housed under open sheds.

\section{1- Experimental rations}

Calves in the first group were fed the control ration that contained on DM basis 55.5\% concentrate mixture (CM) and $45.5 \%$ corn silage (CS)(without additives) while, the calves in the $2^{\text {nd }}$ and $3^{\text {rd }}$ groups were fed the control ration with addition $75 \mathrm{gm}$ of Optigen II (Alltech, Lexington, KY)as feed additives to replace $0.421 \mathrm{~kg}$ of soybean meal which is represented of $1.35 \%$ on dry matter basis (Opt. 75)or100 gm Optigen II(Alltech, Lexington, KY)as a replacer to $0.558 \mathrm{~kg}$ of soybean meal dailywhich is represented of $1.84 \%$ on dry matter basis (Opt. 100), respectively. All tested rations were isocaloric 
and isonitrogenous.The composition of experimental ingredients are shown in Table (1).

Table (1): Ingredient composition of concentrate \% (on DM basis)

\begin{tabular}{lccc}
\hline \multirow{2}{*}{ Item } & \multicolumn{3}{c}{ experimental rations \% DM } \\
\cline { 2 - 4 } & $\begin{array}{c}\text { G1 } \\
\text { (Control) }\end{array}$ & $\begin{array}{c}\text { G2 } \\
\text { (Opt. 75) }\end{array}$ & $\begin{array}{c}\text { G3 } \\
\text { (Opt. 100) }\end{array}$ \\
\hline Beat pulp & & & 9.20 \\
Soybean meal & 8.4 & 9.00 & 30.10 \\
Yellow corn & 37.60 & 32.08 & 42.30 \\
Wheat bran & 38.80 & 41.40 & 12.90 \\
Calcium carbonate & 11.80 & 12.60 & 0.92 \\
Minerals \& Vitamins & 0.84 & 0.90 & 1.10 \\
Salt & 1.01 & 1.08 & 0.72 \\
Sodium bicarbonate & 0.68 & 0.70 & 0.72 \\
Yeast & 0.68 & 0.70 & 0.02 \\
Anti-toxic & 0.02 & 0.02 & 0.18 \\
Optigen & 0.17 & 0.17 & 1.84 \\
\hline Total & 0.00 & 1.35 & 100 \\
\hline
\end{tabular}

\section{2- $\quad$ Feeding system}

Animals were fed to cover their recommend requirement according to NRC(1996).Animals were weighed before morning feeding bi-weekly and the feeding allowances for animals were adjusted based on body weight change. The control and experimental rations were offered once daily at 8 a.m. with TMR (total mixed ration) feeding system. Fresh water was available continuously. Three digestibility trails were conducted during the feeding period (at the middle) using 3 calves from each group to determine the digestibility and nutritive values of the experimental ration by using acid insoluble ash (AIA) as a natural marker (Van keulen and Young, 1997). Chemical analysis of different ingredients, experimental rations and feces were carried out according to the methods of A.O.A.C. (2012).

Rumen liquor samples were taken from three calves from each group after $3 \mathrm{hr}$. from the morning feeding using stomach tube. Every sample was strained through four layers of cheese cloth. Rumen $\mathrm{pH}$ was determined immediately after straining the samples using Orion SA 210 digital pH meters. The total volatile and individual fatty acids were determined in rumen liquor by the steam distillation methods described by (Warner, 1964). Ammonia nitrogen was determined using saturated solution of magnesium oxide distillation according to the methods of A.O.A.C. (2012).

Animals were weighed before morning feeding on two consecutive days at beginning and at the end of the trial, average daily gain, feed conversion ratio and economic efficiency were calculated. 
The data were statistically analyzed using general linear model procedure adapted by SPSS for Windows (2008) for one-way ANOVA. Duncan test within program of SPSS was done to determine the degree of significant among the means.

\section{1- Chemical composition}

\section{RESULTS AND DISCUSSION}

Chemical composition of different ingredients and experimental rations (on DM basis) is shown in Table (2). The data showed that the chemical composition of experimental ingredients are within the normal range of chemical analysis of feedstuffs used in Egypt as mentioned by APRI(1997) and CLFF(2001).

Data also in Table 2. showed that the chemical composition of experimental concentrate was isocaloric and isonitrogenous (approximately similar in their content of all nutrients, DM, CP, CF, EE, ADF, NDF, NFE and ash).

Table (2): Chemical composition of different ingredients and concentrate mixture used in feeding Holstein calves (on DM basis)

\begin{tabular}{|c|c|c|c|c|c|c|}
\hline Item & $\begin{array}{l}\text { corn } \\
\text { silage }\end{array}$ & $\begin{array}{l}\text { soybe } \\
\text { an }\end{array}$ & $\begin{array}{l}\text { beat } \\
\text { pulp }\end{array}$ & $\begin{array}{c}\text { Wheat } \\
\text { bran }\end{array}$ & $\begin{array}{l}\text { yellow } \\
\text { corn }\end{array}$ & Optigen \\
\hline DM & 25.8 & 91.7 & 93.3 & 90.69 & 90.74 & -- \\
\hline OM & 91.53 & 92.62 & 95.98 & 95.42 & 98.66 & -- \\
\hline CP & 7.44 & 50.1 & 9.41 & 16.31 & 7.97 & 256 \\
\hline EE & 1.92 & 1.05 & 0.81 & 3.01 & 4.68 & -- \\
\hline CF & 26.87 & 2.36 & 19.76 & 5.11 & 1.41 & -- \\
\hline NFE & 55.30 & 39.11 & 66.00 & 70.99 & 84.60 & -- \\
\hline NDF & 61.43 & 10.1 & 53.8 & 35.69 & 10.98 & -- \\
\hline ADF & 34.83 & 3.38 & 28.7 & 10.39 & 4.35 & -- \\
\hline Cellulose & 30.85 & 2.87 & 24.2 & 7.75 & 2.88 & -- \\
\hline $\begin{array}{l}\text { Hemicellulo } \\
\text { se }\end{array}$ & 26.6 & 6.75 & 25.1 & 25.29 & 6.63 & -- \\
\hline Lignin & 3.98 & 0.51 & 4.44 & 2.64 & 1.47 & -- \\
\hline NDFIP & 1.43 & 1.76 & 6.33 & 3.59 & 0.77 & -- \\
\hline ADFIP & 1.23 & 0.67 & 2.32 & 0.8 & 0.76 & -- \\
\hline NFC & 20.75 & 31.3 & 32 & 40.41 & 75.02 & -- \\
\hline \multirow[t]{3}{*}{ Ash } & 8.47 & 7.38 & 4.02 & 4.58 & 1.34 & -- \\
\hline & \multicolumn{6}{|c|}{ Concentrate mixture for experimental rations $\%$ DM basis } \\
\hline & \multicolumn{2}{|c|}{ G1(Control) } & \multicolumn{2}{|c|}{ G2(Opt. 75) } & \multicolumn{2}{|c|}{ G3(Opt. 100) } \\
\hline DM & \multicolumn{2}{|c|}{91.10} & \multicolumn{2}{|c|}{92.00} & \multicolumn{2}{|c|}{93.60} \\
\hline OM & \multicolumn{2}{|c|}{96.10} & \multicolumn{2}{|c|}{96.30} & \multicolumn{2}{|c|}{96.60} \\
\hline $\mathbf{C P}$ & \multicolumn{2}{|c|}{23.30} & \multicolumn{2}{|c|}{24.00} & \multicolumn{2}{|c|}{24.00} \\
\hline CF & \multicolumn{2}{|c|}{4.62} & \multicolumn{2}{|c|}{3.86} & \multicolumn{2}{|c|}{4.13} \\
\hline NDF & \multicolumn{2}{|c|}{21.51} & \multicolumn{2}{|c|}{23.32} & \multicolumn{2}{|c|}{23.10} \\
\hline ADF & \multicolumn{2}{|c|}{11.83} & \multicolumn{2}{|c|}{11.37} & \multicolumn{2}{|c|}{10.47} \\
\hline EE & \multicolumn{2}{|c|}{2.63} & \multicolumn{2}{|c|}{3.10} & \multicolumn{2}{|c|}{3.29} \\
\hline NFE \% & \multicolumn{2}{|c|}{65.55} & \multicolumn{2}{|c|}{65.34} & \multicolumn{2}{|c|}{65.18} \\
\hline Ash & \multicolumn{2}{|c|}{3.90} & \multicolumn{2}{|c|}{3.70} & \multicolumn{2}{|c|}{3.40} \\
\hline
\end{tabular}




\begin{tabular}{|l|c|c|c|}
\hline \multicolumn{4}{|c|}{ Calculated experimental rations on DM basis } \\
\hline OM & 94.06 & 94.02 & 94.08 \\
\hline CP & 16.25 & 15.92 & 15.59 \\
\hline CF & 14.58 & 15.05 & 15.48 \\
\hline EE & 2.29 & 2.30 & 2.47 \\
\hline NFE & 60.94 & 60.75 & 60.54 \\
\hline Ash & 5.94 & 6.02 & 6.13 \\
\hline
\end{tabular}

\section{2- Nutrients digestibility and digestibility coefficient:}

The data in Table (3) showed that no significant differences in digestibilities for all nutrientsbut the ether extract digestibility coefficient was significantly higher for G2 and G3 compared with the control ration. The animals in G2 (opt. 75) had the highest digestibility coefficients of all nutrients followed by animals in G3 (opt. 100), while the control group had the lowest values. The improvement in digestibility coefficients could be illustrated on the basis that optigen can play indirect role to stimulate anaerobic fermentation of dry mater that improve the utilization efficiency of nutrients and direct role to improve digestion in abomasum. These results are in a good agreement with this obtained by Taylor-Edwards et al. (2009)who stated that although apparent total tract digestibilities of DM, OM, NDF and ADF were not affected by treated with slow release urea. But, fecal $\mathrm{N}$ excretion increased and apparent total tract $\mathrm{N}$ digestibility reduced. Intake of DM, OM, NDF, and ADF did not differ among treatments and there were no detrimental effects on DM and fiber digestibility associated with feeding a slow release urea. Moreover, Bruno et al, (2015)found that the replacing of soybean meal by slow release urea did not show differences for DM, CP and NDF digestibility.

Table 3: Feed intake, digestibility coefficient and nutritive value for different experimental ration fed to steers (mean $\pm \mathrm{SE}$ )

\begin{tabular}{|l|c|c|c|c|}
\hline \multirow{2}{*}{ Item } & \multicolumn{4}{|c|}{ Experimental rations \% DM } \\
\cline { 2 - 5 } & $\begin{array}{c}\text { G1 } \\
\text { (Control) }\end{array}$ & $\begin{array}{c}\text { G2 } \\
\text { (Opt. 75) }\end{array}$ & $\begin{array}{c}\text { G3 } \\
\text { (Opt. 100) }\end{array}$ & $\begin{array}{l}\text { Overall } \\
\text { mean } \pm \text { SE }\end{array}$ \\
\hline DM & 72.90 & 77.60 & 76.90 & $75.80 \pm 1.11$ \\
\hline CP & 83.50 & 87.80 & 86.70 & $86.00 \pm 1.17$ \\
\hline NDF & 73.20 & 70.60 & 73.50 & $72.43 \pm 1.3$ \\
\hline ADF & 54.60 & 60.70 & 58.20 & $57.83 \pm 1.13$ \\
\hline EE & $58.30^{\mathrm{a}}$ & $62.10^{\mathrm{b}}$ & $61.50^{\mathrm{b}}$ & $60.63 \pm 1.16$ \\
\hline NFE & 72.30 & 73.60 & 69.60 & $71.83 \pm 1.8$ \\
\hline Nutritive value & 58.89 & 62.19 & 61.69 & $60.92 \pm .51$ \\
\hline TDN & 13.57 & 13.98 & 13.52 & $14.33 \pm .20$ \\
\hline DCP
\end{tabular}

Means with different superscripts within the same row are significantly different $(P<0.05)$ 
The nutritive values expressed as TDN or DCP for animals in groups II (Opt. 75) and III (Opt. 100) were slightly higher ( $P>0.05)$ compared with the control group. This may be due to the slow-release urea diets prolong microbial utilization of additional $\mathrm{N}$ sources during ruminal fermentation. Sinclair et al., (2012)concluded that the partial replacement of soybean meal and rapeseed meal with feed grade urea or a slow-release urea can be achieved without affecting milk performance or diet digestibility, with the efficiency of conversion of dietary $\mathrm{N}$ into milk being improved when the slow-release urea was fed.

\section{3- Rumen liquor parameters:}

The effect of optigen supplementation on rumen liquor parameters for calves fed the different experimental rations are shown in Table (4). There were no significant differences $(p>0.05)$ in $\mathrm{pH}$ value among the different experimental group during the trial period. These values are within the normal range (6.5- 6.8) obtained byVan Soest (1982) and Taylor-Edwards et al., (2009). The $\mathrm{NH}_{3}-\mathrm{N}$ concentration were significantly $(p<0.05)$ differences among the different groups The highest concentration of rumen $\mathrm{NH}_{3}-\mathrm{N}$ was recorded with feeding 100 gm optigen G3 $(9.56 \mathrm{mg} / 100 \mathrm{ml})$,followed by $\mathrm{G} 2(8.03 \mathrm{mg} / 100 \mathrm{ml})$ .These findings suggest that $\mathrm{N}$ from the Optigen diet could be degraded faster than $\mathrm{N}$ from control diet with soybean meal, but probably slower than common urea. This idea was in part confirmed by Harrison et al., (2007) who found that $\mathrm{NH}_{3}-\mathrm{N}$ concentrations withcoated urea $(\mathrm{CU})$ were lower than those from common urea.

The concentration of TVF's in rumen liquor of calves as affected by optigen supplementation are showed in Table (6). The concentration of TVF's in the rumen liquor of animals in G2 supplemented with optigen $(75 \mathrm{~g}$ Opt.) was higher significantly $(p<0.05)$ compared with the other groups. The highest value $(p<0.05)$ was recorded by $\mathrm{G} 2(97.5 \mathrm{mml} / 100 \mathrm{ml})$ followed by $\mathrm{G} 1(96.2 \mathrm{mml} / 100 \mathrm{ml})$, while the lowest value of $\mathrm{G} 3(94.8 \mathrm{mml} / 100 \mathrm{ml})$. The were no significant differentces for individual fatty acids (acetate, propionate and valrate percent of TVF's) amoung the all treatments. While, there were significant differentces for butyrate percent of TVF'sbeing 13.46, 13.80 and 12.8 for G1,G2 and G3, respectively. These results suggest that the anaerobic fermentation for release nitrogen as a slow degradation was more efficient and faster yielding more TVF's than that in the control group. 
Table (4): Ruminal parameters for Holistiencalvesfed the experimental rations (Mean $\pm \mathrm{SE}$ )

\begin{tabular}{|l|c|c|c|c|}
\hline \multirow{2}{*}{ Item } & \multicolumn{4}{|c|}{ Experimental rations } \\
\cline { 2 - 5 } & G1(control) & $\begin{array}{c}\text { G2 } \\
\text { (Opt. 75) }\end{array}$ & $\begin{array}{c}\text { G } \\
\text { (Opt. 100) }\end{array}$ & SEM \\
\hline PH & 6.66 & 6.70 & 6.70 & \pm 0.48 \\
\hline $\mathrm{NH3}-\mathrm{N}(\mathrm{mg} / 100 \mathrm{ml})$ & $7.13^{\mathrm{c}}$ & $8.03^{\mathrm{b}}$ & $9.56^{\mathrm{a}}$ & \pm 0.36 \\
\hline TVF`s mml/100ml & $96.2^{\mathrm{b}}$ & $97.5^{\mathrm{a}}$ & $94.8^{\mathrm{c}}$ & \pm 0.41 \\
\hline Individual volatile fatty acids \% \\
\hline Acetate & 52.80 & 52.60 & 52.60 & \pm 0.098 \\
\hline Propionate & 34.10 & 34.06 & 35.13 & \pm 0.217 \\
\hline Butyrate & $13.46^{\mathrm{a}}$ & $13.80^{\mathrm{a}}$ & $12.53^{\mathrm{b}}$ & \pm 0.206 \\
\hline Valrate & 0.46 & 0.46 & 0.46 & \pm 0.002 \\
\hline
\end{tabular}

Means with different superscripts within the same row are significantly different $(\mathrm{P}<0.05)$

\section{4-Feed intake :}

Data of voluntary feed intake (Table 5) indicated that there were insignificant differences among experimental groups in DM,TDN and DCP intake as affected by optigen supplementation. This may be attributed that all tested rations had nearly similar chemical composition (Table2) ,along with nutritive value obtained for all tested rations showed insignificant differences (Table3).

\section{5-Animal performance :}

The effect of optigen supplementation on animal's performance is showed in Table (5). There were no significant differences $(p>.05)$ in the average daily gain among the different experimental group during the trial period. Calves in $\mathrm{G} 2$ recorded the highest value of average daily gain compared to the other groups (1.39 vs. 1.35 and 1.25 $\mathrm{kg} /$ day), while the G3 (100g Opt.) had the lowest value. These result confirmed with the result of Pinos-Rodríguez et al., (2010) who reported that usage of optigen at $1 \%$ dry matter can replace soybean meal in diets for beef steers without any negative effect on growth performance. The same trend was also reported by Silveria et al., (2012); Bruno et al, (2015); Fernado et al,.(2014) and Tedeschi et al., (2002).

These results are agree also with those reported by Walker et al., (2000) who foundthat the replacement SBM with slow release urea (RumaPro.) at different levels, 0, 33, 66 and $100 \%$ of the supplemental $\mathrm{CP}$ by Ruma Pro. ADG were not significant $(\mathrm{P}<0.1)$. Steers fed Ruma Pro at $33 \%$ consumed less feed than control steers. For the overall feeding period, feed:gain was improved $(P<0.01)$ for steers fed Ruma Pro vs. control. However,Fernadoetal. (2014) and Gonçalveset al., (2014) indicated that the replacement of soybean meal by slow- 
release urea (SRU) does not affect the variables of intake and digestibility of dry matter or milk production of crossbred cows. The same results reported by Pinos-Rodríguez et al., (2010) with beef steers.

Results of feed conversion ( $\mathrm{kg}$ feed / $\mathrm{kg}$ gain ) expressed as DM,TDN and DCP were nearing similar for all experimental groups without significant differences (Table 5) this may be due to that experimental calves were received their recommended nutrients allowances (NRC 1996) and covered their recommended requirements Sinclairet al., (2012)and Bruno et al, (2015) reported that the partial replacement of soybean meal and rapeseed meal with feed grade urea or a slow-release urea can be achieved without affecting milk performance or diet digestibility, with the efficiency of conversion of dietary $\mathrm{N}$ into milk being improved when the slow-release urea was fed.

There were no significant differences $(p>0.05)$ in average daily feed cost for steers during the experiment period $(20.98,21.19$ and 21.24 L.E for G1, G2 and G3, respectively). While feed cost/ $\mathrm{kg}$ gain increased significantly for animals in group 3 compared with other groups being 17.0 vs. 15.2 and $15.02 \mathrm{~L}$. E for the control group and $\mathrm{G}$ 2 , respectively.

The supplementation of $75 \mathrm{gm}$ optigen improved the income of daily gain (net revenue) by 5.23 and $27.38 \%$ compared with the control and G3 (100g Opt.), respectively. The same trend was also reported for feed conversion (6.69 vs. 7.11 and 7.44 feed intake/ kg gain for G2, control and G3, respectively). these result are according with these obtained by Pinos-Rodríguez et al.,(2010) and Inostroza et al., (2010) who found that animals fed rations supplemented with optigen were more economically efficient than those fed non supplemented rations.

The best economic efficiency and relative economic efficiency were recorded by the $\mathrm{G} 2$ (supplemented by $75 \mathrm{gm}$ optigen) while the lowest economic efficiency was recorded by the G3 (supplemented by $100 \mathrm{gm}$ optigen), While the control group had the intermediate value. 
Table (5): Effect of optigen supplementation on average daily feed intake, animals' performance and economic efficiency of steers fed the different experimental rations

\begin{tabular}{|c|c|c|c|c|}
\hline \multirow[b]{2}{*}{ Item } & \multicolumn{4}{|c|}{ Experimental rations } \\
\hline & $\begin{array}{c}\text { G1 } \\
\text { (Cont.) }\end{array}$ & $\begin{array}{c}\text { G2 } \\
\text { (Opt. 75) }\end{array}$ & $\begin{array}{c}\text { G3 } \\
\text { (Opt. 100) }\end{array}$ & $\begin{array}{c}\text { Overall mean } \pm \\
\text { SE }\end{array}$ \\
\hline \multicolumn{5}{|c|}{ Average daily feed intake as DM (kg per calves /day) } \\
\hline Feed intake kg DM/ day & 9.6 & 9.3 & 9.3 & $9.4 \pm 0.05$ \\
\hline TDN intake & 5.65 & 5.78 & 5.74 & \\
\hline DCP intake & 1.30 & 1.30 & 1.26 & \\
\hline Initial body weight/kg & 255.4 & 269.8 & 255.6 & $260.26 \pm 13.25$ \\
\hline Final body weight/ kg & 380.8 & 399.07 & 371.6 & $383.80 \pm 13.46$ \\
\hline Total gain & 125.4 & 129.27 & 116.0 & $123.5 \pm 2.69$ \\
\hline Daily gain $\mathrm{kg} /$ day & 1.35 & 1.39 & 1.25 & $1.32 \pm 0.029$ \\
\hline \multicolumn{5}{|l|}{ Feed conversion } \\
\hline $\mathrm{kg} \mathrm{DM} / \mathrm{kg}$ gain & 7.11 & 6.69 & 7.44 & $7.08 \pm 0.25$ \\
\hline $\mathrm{kg}$ TDN/kg gain & 4.18 & 4.15 & 4.58 & $4.3 \pm 0.068$ \\
\hline $\mathrm{kg} \mathrm{DCP} / \mathrm{kg}$ gain & 0.95 & .98 & 1.08 & $1.01 \pm 0.019$ \\
\hline \multicolumn{5}{|l|}{ Economic efficiency } \\
\hline Feed cost/ head/ daily/ L. E & 20.98 & 21.19 & 21.24 & $21.13 \pm 0.30$ \\
\hline Feed cost/ kg gain/ L.E. & $15.54^{b}$ & $15.24^{b}$ & $17.00^{\mathrm{a}}$ & $16.01 \pm 0.35$ \\
\hline Total revenue (L. E.) & 39.15 & 40.31 & 36.25 & $38.52 \pm 0.84$ \\
\hline Net revenue (L. E.) & 18.17 & 19.12 & 15.01 & $17.38 \pm 3.84$ \\
\hline Economic efficiency (\%). & 86.61 & 90.23 & 70.67 & \\
\hline Relative economic efficiency to control & 100 & 1.05 & 82.61 & \\
\hline
\end{tabular}

The calculations based on local price of year 2014: Corn silage:300 L.E. / ton. Soybean meal:3802 L.E. / ton. Yellow corn ground: 1678 L.E. / ton. Wheat bran:2020 L.E. / ton. Beet pulp: 1860L.E. / ton.Optigen: 25000 L.E. / ton.,Body live weight $=29$ L.E. / kg

The result of the present study indicated that the replacing soybean meal is as potential plant protein source with optigen as a slow release urea at different levels didn't effect on feed intake, but the supplementation of optigen at level $75 \mathrm{gm} /$ day (1.35\% on DM basis) improved the digestibility coefficients for all the nutrients. The animals in G2 (Opt. 75) gained $11.2 \%$ more than those in G3 (Opt. 100) as well as improved the income of daily gain (net revenue) by 5.23 and $27.38 \%$ compared with the control and G3 (Opt.100), respectively. Finally it can be recommended that the supplementation of optigen at level $75 \mathrm{gm} /$ day $(1.35 \%$ on DM basis) was more economically efficiency.

\section{REFERENCES}

Ana,P.G.; F.M. Carolina; A.F. Fernanda; D.C. Rodrigo; D.Q. Marcelo; T.M. Carolinaand, J.M. João (2015). Slow-release Urea in Supplement Fed to Beef Steers. Brazilian Archives of Biology and Technology.58:22-30.

APRI(1997). Scientific and Practical of Animal Nutrition. $1^{\text {st }}$ (in Arabic ) Animal Production RerearchInstitute.AgricultureResrarch Center Ministry of Agriculture.

AOAC. (2012). Official methods of analysis of AOAC International. 19 ed. Association of official analytical chemists, Arlington, VA. 
Arosemena, A.; E.J. depeters and J.G. Fadel (1995). Extent of variability in nutrient composition within selected by-product feedstuffs. anim. feeds sci. technol:103120.

Baker,L.D.; J.D. Ferguson and W. Chalupa (1995). Responses in Urea and True Protein of Milk to Different Protein Feeding Schemes for Dairy Cows. J. dairy Sci. 24:34.

Bartley,T.E. and C.W.Deyoe (1975). Starea as a protein replacer for ruminants. Feedstutfs.47:42.

Benedeti, P.D.; P. V.Paulino; M. I. Marcondes; S.C.ValadaresFilho; T .S. Martins; E.F. Lisboa; L.H.Silva; C.R.Teixeira and M.S. Duarte (2014). Soybean meal replaced by slow release urea in finishing diets for beef cattle. Livestock Science 165: 5160 .

Bourg,B.M.; L.O.Tedeschi; T.A.Wickershamand J. M. Tricarico(2012). Effects of a slow-release urea product on performance, carcass characteristics, and nitrogen balance of steers fed steam-flaked corn. J.Anim. Sci.

Broderick, G.A. and S.M. Reynal (2009). Effect of source of rumen-degraded protein on production and ruminal metabolism in lactating dairy cows. J. Dairy Sci. 92:2822.

Bruno,T.S.; S.D. JunqueiraVillela; F.P. Leonel; J.T. Zervoudakis; R. PavesiAraújo; H.V. Machado; L. M. Moreira and T. S. Oliveira (2015). Slow-release urea in diets for lactating crossbred cows. J. Anim. Sci.44:193-199.

Cass,J.L. and C.R. Richardson (1994). In vitro ammonia release from urea-calcium compounds as compared to urea and cottonseed meal. Texas Tech. Univ. Agr.Sci. Natl. Res.5-342.

Chalupa, W. (2007). Precision feeding of nitrogen to lactating dairy cows: A role for Optigen II. in Nutritional Biotechnology in the Feed and Food Industries.221.

Cherdthong, A.; M. Wanapat; C. Wachirapakorn and M. E. Amburgh (2010). Evaluation of ureacalcium mixtures (UCM) as slow-release: I. Fermentation characteristics using in vitro gas technique. In: Proceedings of the AgricultureConference11th. January 25-26, 2010. KaweeJutikul Auditorium, KhonKaen University, KhonKaen, Thailand, pp: 138-141.

Conrad, H. R. and J. W. Hibbs (1968). Nitrogen utilization by the ruminant. Appreciation of its nutritive value. J. Dairy Sci.60: 1725-1733.

CLFF(2011).feed composition for animal and poultry feedstuffs used in Egypt Technical Bulletin Nr.1.Central Lab for food \& feed(CLFF) Agriculture research center .Ministry of Agriculture.

Deyoe, C.; E. Bartley; H. Pfost; F. Boren; H. Perry; F.Anstaett; L.Helmer; D.Stiles; A.Sung and R.Meyer (1968). An improved urea product for ruminants. J. Anim. Sci.27:1163.

Douglas, M.W.; C. M. Parson and M.R. Redford (2000). Effected of various soya bean meal sources and avizyme on chick growth performance and lead digestible energy.j.appl.poultry.res.80:94.

Ferme,D.; M. Banjac; S.Calsamiglia; M.Busquet,C.Kamel and G.Avgustin(2004). The effects of plant extracts on microbial community structure in a rumen-simulating continuous-culture system as revealed by molecular profiling. Folia.Microbiol.151:155.

Firkins,J.L.;Z.Yuand and M.Morrison(2007).Ruminalnitrogen metabolism perspectives for Integration of microbiology and nutrition for dairy. J. Dairy Sci.1:16.

Fishwick, G. (1978).Some effects of coating urea prills with sulfurand wax on nitrogen utilization by ruminants. Brit. Vet. J.134:578.

Galina, M. A.; F. Perez-Gil; R. M. Ortiz; J. D. Hummel and R.E. Ørskov (2003). Effect of slow release urea supplementation on fattening of steers fed sugar cane tops 
(Saccharumofficinarum) and maize (Zea mays): ruminal fermentation, feed intake and digestibility. Livest. Prod. Sci.1-11.

Galo, E.; S. M. Emanuele; C. J. Sniffen; J. H. White and J. R. Knapp (2003). Effects of a polymer-coated urea product on nitrogen metabolism in lactating Holstein dairy cattle. J. Dairy Sci.2154-2162.

Garrett, J.; T. Miller-Webster; W. Hoover; C. Sniffen and D. Putnam (2005). Encapsulated slow release urea in lactating dairy cow diets impacts microbial efficiency and metabolism in continuous culture. J. Anim. Sci 83: 321.

Golombeski, G. L.; K. F. Kalscheur; A. R. Hippen and D. J. Schingoethe (2006). Slowrelease urea and highly fermentable sugars in diets fed to lactating dairy cows. J. Dairy Sci.4395-4403.

Gonçalves, G. S.; M. S. Pedreira; J. A. Azevedo; A. J. DelRei; H.G.Silva and F. F.Silval (2014). Replacement of soybean meal by conventional and coated urea in dairy cows: intake, digestibility, production and composition of milk. Maringa 36:71-78.

González-Muñoz, S. S.; J. M. Pinos-Rodríguez; Y.López-Hernández and L. A. Miranda (2014). Effects of slow-release urea on in vitro degradation of forages. J. of Animal and Plant Sciences.1840:1843.

Griswold, K. E.; G. A. Apgar; J. Bouton and J. L. Firkins (2003). Effect of urea infusion and ruminal degradable protein concentration on microbial growth, digestibility, andfermentation in continuous culture. J. Anim. Sci. 329-336.

Gustavo, D.; R. Gardinal; B . C. Venturelli; J. D. FreitasJúnior; T. H. Annibale; H. D. Souza and F. P. Rennó (2015). Effects of polymer-coated slow-release urea on performance, ruminal fermentation, and blood metabolites in dairy cows.j.of.anim.Sci.327:334.

Hans, H. S.; L. L. Berger; J. K. Drackley; G. F. Fahey; D. C. Hernot and C. M. parsons (2008). Nutrion properties and feeding values of soya beans and their products.619:662.

Harrison, G. A.; M.D. Meyer and K.A. Dawson (2007). Effect of Optigen and dietary neutral detergent fiberlevel on fermentation, digestion, and $\mathrm{N}$ flow in rumensimulating fermenters. J. Dairy Sci.91:489.

Highstreet,A.; P.H.Robinson; J.Robison and J.G. Garrett ( 2010). Response of Holstein cows to replacing urea with a slowly rumen released urea in a diet high in soluble crude protein. Livest. Sci. 179-185.

Hira,A.K.; M.Y.Ali; M.Chakraborty; M.A.Islam and M.R.Zaman (2002). Use of water hyacinth leaves (Eichhorniacrassipes) replacing adhal grass (Hymenachnepseudointerrputa) in the diet of goats. pakistan j.bio.sci.218:220.

Holder,V.B.; J.M.Tricarico; D.H.Kim; N.B.Kristensenand D.L. Harmon (2015). The effects of degradable nitrogen level and slow release urea on nitrogen balance and urea kinetics in Holstein steers. Animal Feed Science and Technology.abst.

Huntington, G.B.; D.L. Harmon; N.B. Kristensen; K.C. Hanson and J.W. Spears (2006). Effects of a slow release urea source on absorption of ammonia and endogenous production of urea bycattle.Anim. Feed Sci.Tech.225-241.

Huston, J.E.; M. Shelton and L.H. Brewer (1974). Effects of rate ofrelease of urea on its utilization by sheep. J. Anim. Sci.39:618.

Inostroza,J. F.; R.D.Shaver; V.E.Cabrera and J.M.Tricárico(2010). Effect of Diets Containing a Controlled-Release Urea Product on Milk Yield, Milk Composition, and Milk Component Yields in Commercial Wisconsin Dairy Herds and Economic Implications. Professional Animal Scientist, 26:175-180. 
Leng,R.A. and J.V.Nolan (1984). Nitrogen metabolism in the rumen. J. Dairy Sci.10721089.

Ludden, P. A., D. L. Harmon, G. B. Huntington, B. T. Larson, and D. E. Axe. (2000). Influence of the novel urease inhibitor N-(nbutyl) thiophosphorictriamide on ruminant nitrogen metabolism: II.Ruminal nitrogen metabolism, diet digestibility, and nitrogen balance in lambs. J. Anim. Sci. 78:188-198.

Males, J. R.; R.A.Munsingen and R.R. Johnson (1979). In vitro and in vivo ammonia release from "slow release" urea supplements.J. Anim. Sci. 48:887.

Nadi, M. A.; I. M.Pop (2013). Research on chemical composition of corn silo obtained in different production systems (conventional and organic). lucaristiintifice-seria 200 tehnie.59.

Nocek,J.E. and J.B.Russell (1988). Protein and energy as an integrated system. Relationship of ruminal protein and carbohydrate availability to microbial synthesis and milk production. J. Dairy Sci.2070:2107.

Noguera,R.R.; S.L.Posada and C.I.Restrepo (2015). Comparison of slow-release urea sources on in vitro degradation of King grass (Pennisetumpurpureum $\times$ pennisetumtyphoides). Livestock Research for Rural Development. Abstr.

NRC.(1996).Nutrient Requirements of beefCattle.Seventh Revised Edition, TheNational Academies Press.washington.

Oltjen, R. K. (1969). Effects of feeding ruminants non-protein nitrogen

Oltjen,R.K.; W. CBurns and C.R.Ammerman (1974). Biuret versus ureaand cottonseed meal for wintering and finishing steers. J. Anim.Sci. 38:975.

Orskov,E.P.; R.Smart and A.Z.Mehrez (1974). A method of including urea irnole grains. J. Agri. Sci.83:299.

Owens,F.N.; K.S.Lusby; K.Mizwicki and O. Forero (1980). Slow ammonia release from urea: Rumen and metabolism studies. J. Anim. Sci.50:527-531.

Paul,J.K.;B.janicek (2009).Understanding milling feed byproducts for dairy cattle.j.dai.sci.14:20.

Pinos-Rodríguez, J.M.; L.Y.Peña; S.S.González-Muñoz; R.Bárcena and A.Salem (2010). Effects of a slow-release coated urea product on growth performance and ruminal fermentation in beef steers. Italian J. Anim. Sci.10.4081

Prokop,M.J. and T.J.Klopfenstein (1977). Slow ammonia release urea. Nebraska Beef Cattle Report No.EC 77-218 Nebraska.

Puga,D.C.; H.M.Galina; R.F.Perez-Gil; G.L.Sangines; B.A.Aguilera and G.F.Haenlein (2001). Effect of a controlled-release urea supplement on rumen fermentation in sheep fed adiet of sugar cane tops (Saccharumofficinarum), corn stubble (Zea mays) and King grass (Pennisetumpurpureum). Small Rumin. Res., 39: 269-276.

Ruiz-Moreno,M.J.;N.DiLorenzo; I.Ceconi; A.DiCostanzo and G.I.Crawford (2015). Effect of slow-release urea inclusion in diets containing modified corn distillers grains on total tract digestibility and ruminal fermentation in feedlot cattle. Journal of Animal Science October:4058-4069 Abst.

Sinclair,L. A.; C.W.Blake and G.H.Jones (2012). The partial replacement of soybean meal and rapeseed meal with feed grade urea or a slow-release urea and its effect on the performance, metabolism and digestibility in dairy cows. Anim.dairy.sci. June 6 (6): 920-7 Abst.

SPSS Inc. Released (2008). SPSS Statistics for Windows, Version 17.0. Chicago: SPSS Inc.

Sultansingh,S.K.; A.S.Negi and V.C.Pachouri (2010). Performance of growing kids on rations with lablab (lablab purpureus) grains as protein source indian grassland and fooder research instituted, india.

Taghizadeh,A.; M. Mesoran; R. Valizadeh; F. EftekharandK. Stanford (2005). Digestion of fee of steers measured using a mobile nylon pag technique.j.dai.sci.1807:1814 
Taylor-Edwards,C.C.; N.A. Elam; S.E.Kitts; K.R.McLeod; D.E.Axe; E.S. Vanzant; N.B.Kristensen and D.L.Harmon (2009). Influence of slow-release urea on nitrogen balance andportal-drained visceral nutrient flux in beef steers. J. Anim. Sci.87:209-221.

Tedeschi,L.O.; D.G.Fox; M.J.Baker; and D. P. Kirschten (2006). Identifyingdifferences in feed efficiency among group-fed cattle.J.of Ani.Sci.767-776.

Tedeschi,L.O.; M.J.Baker; D.J.Ketchen and D. G. Fox (2002). Performance of growing and finishing cattle supplementedwith a slow-release urea product and urea.Can. J. Anim. Sci.82:567-573.

Tikofsky,J. and G.A.Harrison (2007). Optigen II Improving the efficiency of nitrogen utilization in the dairy cow. In Nutritional Biotechnology in the Feed and Food Industries.373.

Van keulen,J. and B.A.Young (1977). Evaluation of acid-insoluble ash as a natural marker in ruminant digestibility studies.j.anim.sci.44:282-287

Van Soest,P.J. (1982). Nutritional ecology of the ruminant.2nd ed. Cornell University Press. Ithaca, NY, USA, pp: 476.

Vaughn,B.H.; S.W.El-Kadi; J.M.Tricarico; E.S.Vanzant; K. R. McLeod and D.Harmon (2013). The effects of crude protein concentration and slow release urea on nitrogen metabolism in Holstein steers. J. Anim. nutr.93:103.

Waite,R. and A.G.Wilson (1968). The composition of rumen fluid from cows fed biuret and urea. abst.

Walker,D.A.; G.C..Duff; K. J. Malcom-callis; M.W.Wiseman; J. D. Rivera; m. I. Galyean and T. H. Montgomery (2000). Effects of a slow-release urea product on feedlot performance and carcass characteristics of beef steers.proceedings, western section,Amer.soc.anim.sci.51:2000.

Wanapat,M.; S. Polyorach; K. Boonnop; C. Manapato and A. Cherdthong (2009). Effects of treating rice straw with urea and calcium hydroxide upon intake digestibility, rumen fermentation and milk yield of dairy cows. Liv. stok. sci.125:238-243.

Warner, A.C.I. (1964). Production of volatile fatty acids in the rumen: methods of measurements.Nutr. Abst. Rev., 34: 339.

Whitelaw,F.G.; J.S.Milne and S.A.Wright (1991). Urease (EC3.5.1.5) inhibition in the sheep rumen and its effect on urea andnitrogen metabolism. Br. J. Nutr.209:225.

William,C.(1968). Problems in Feeding Urea to Ruminants. J. Anim. Sci,.Vol. 27: 207219

Xin,H.S.; D.M.Schaefer; Q.P. Liu; D.E. Axe and Q.X.Meng (2010).Effects of polyurethane coated ureasupplement on in vitro ruminal fermentation, ammonia release dynamics andlactating performance of Holstein dairy cows fed a steamflaked corn-based diet. Asian-Aust. J. Anim. Sci.491:500.S

$$
\begin{aligned}
& \text { تاثير إضافة مستويات من الأوبتجن على أداء العصيوان لعجول التسمين الهولشتين } \\
& \text { نبيل محمد عويضة, محمد بسيونى ,ابراهيم محمود عبدالرازق , محمود عبدالباقى }
\end{aligned}
$$

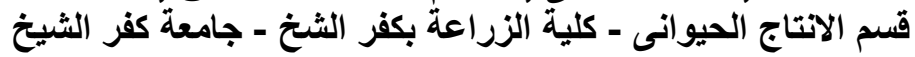

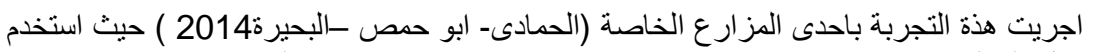

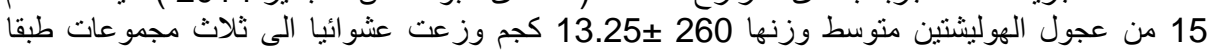

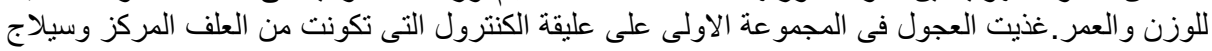

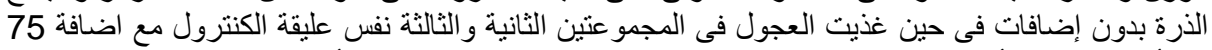

$$
\begin{aligned}
& \text { جم أو } 100 \text { جم أوبتجن كإضافات غذانين إنية بنسبة } 1.35 \text {, } 1.84 \text { \% على أساس المادة الجافة وتم تقدير }
\end{aligned}
$$


معاملات الهضم والقيمة الغذائية لهذة العلائق بالإضافة الى بعض صفات الكرش والأداء الانتاجى والقيمة

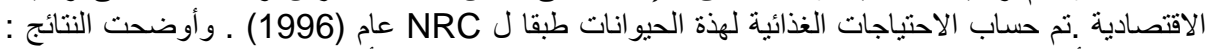

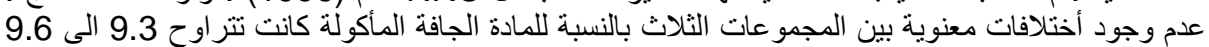

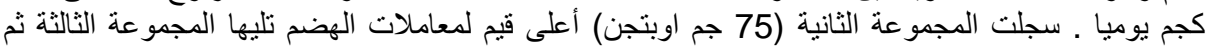

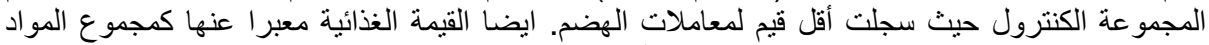

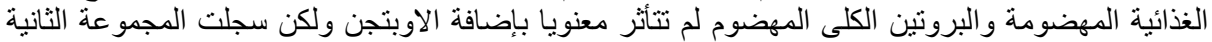

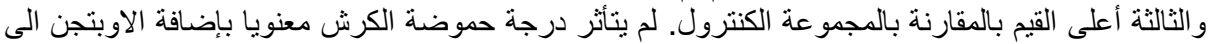

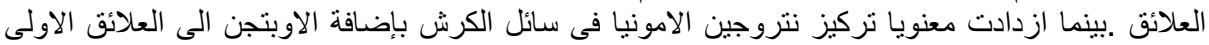

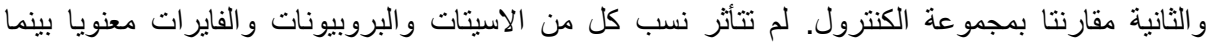

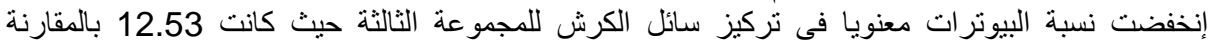

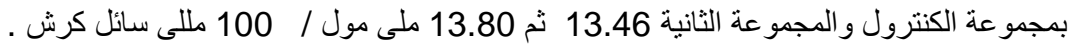

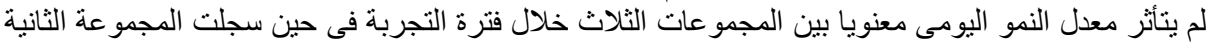

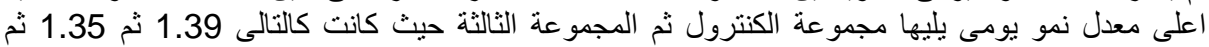

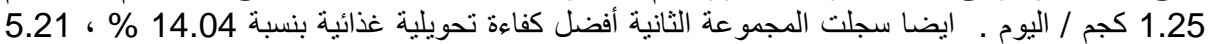

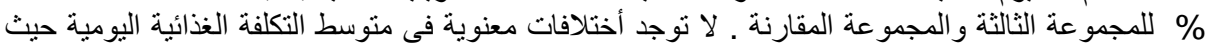

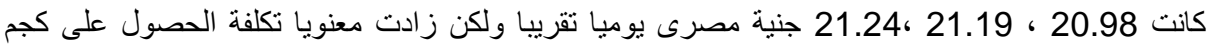

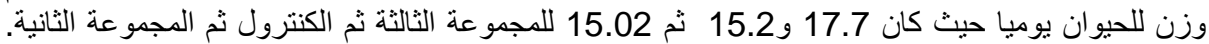

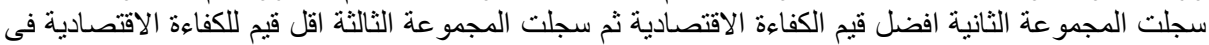

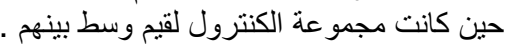

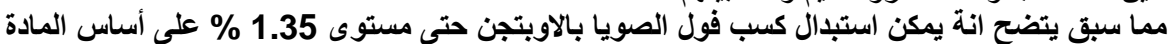

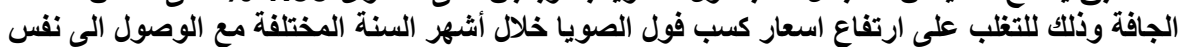

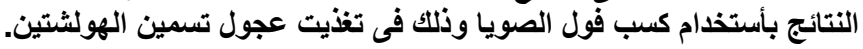

